\title{
CARDIAC OUTPUT CHANGES WITH ALTERED ACID-BASE STATUS DURING METHOXYFLURANE ANAESTHESIA
}

\author{
WILLIAM W. STOYKa, B.SC., F.R.C.P. $(\mathrm{c})^{*}$
}

The Purpose of this study was to determine the effects upon cardiac output of alterations in acid-base states during methoxyflurane anaesthesia in dogs.

Studies of varied acid-base states on cardiac functions have been described in vitro $^{1}$ and in vivo. ${ }^{2.3} \mathrm{~A}$ clear understanding of cause and effect relationships has been prevented by disparity of results, lack of correlation with surface area or weight, and the inability to correlate effects between dogs. Carson et al. ${ }^{4}$ were first to be able to quantitate the separate and opposed effects of change in $\mathrm{pH}$ and $\mathrm{PCO}_{2}$ upon cardiac output in studies in dogs with pentobarbital. Cardiac output was shown to be linearly related to $\mathrm{pH}$ and exponentially related to $\mathrm{PCO}_{2}$. From this data, a nomogram was presented in which changes in cardiac output could be predicted from variations in $\mathrm{pH}$ and $\mathrm{PCO}_{2}$. Similar relationships have been described by Tomlin et al. ${ }^{5}$ in dog studies with halothane, and by Stoyka et al. ${ }^{6}$ in studies with fluroxene in dogs. The present study proposes to determine whether similar effects upon cardiac output are produced by varied acid-base states during methoxyflurane anaesthesia.

\section{Methods}

Mongrel male dogs, with chronically implanted electromagnetic flow probes on the ascending aorta, were induced with thiopentone and the trachea was intubated. Anaesthesia was maintained with a constant expired concentration of 0.23 per cent methoxyflurane (MAC-1) ${ }^{7}$ using a copper kettle vaporizer. Ventilation was achieved with a volume controlled animal respirator during succinyleholine apnoea. Expired carbon dioxide was monitored with an infra-red analyzer to facilitate maintenance of ventilation appropriate to an arterial carbon dioxide tension of $40 \pm 3$ torr.

The femoral artery was cannulated and blood pressure was recorded using a resistance transducer. Arterial cannulation allowed blood sampling for determinations of arterial $\mathrm{pH}, \mathrm{PO}_{2}, \mathrm{PCO}_{2}$ and electrolytes. Arterial blood levels of methoxyflurane were determined by gas chromatography. $A$ central venous pressure catheter was inserted for measurement and intravenous infusions. Oesophageal temperature was measured by a telethermometer and maintained at $37 \pm 1^{\circ} \mathrm{C}$. Blood gas analyses were corrected to animal temperature using appropriate correction factors. ${ }^{8,0}$

Figure I illustrates the laboratory set up which is utilized for this study.

The electromagnetic flow probe was connected to a recording dynograph and a flow wave was obtained. An integral of this wave form was triggered by the electrocardiogram QRS to obtain a trace of stroke volume for each heart beat, acoording to

"From the Department of Anaesthesia, University of Toronto and St Michael's Hospital, Toronto. 


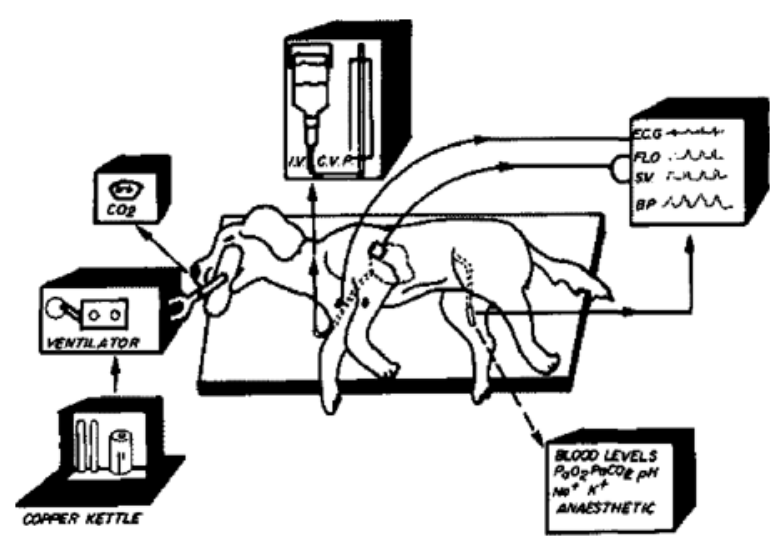

Ficure 1

Illustration of the methodology and parameters to be measured in this study.

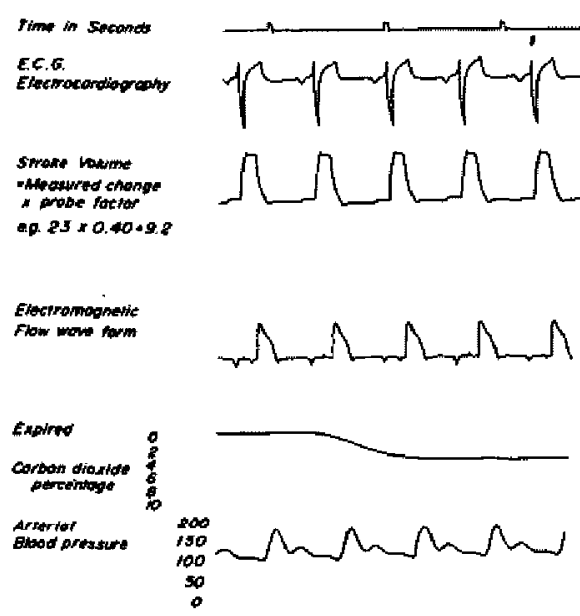

Figure 2

A tracing of the recorded How wave form ampli-

fied and integrated to obtain stroke volume.

Other data are included in this tracing.

the method of Scher ${ }^{10}$ Comparison of this method for determination of cardiac output with that of dye dilution technique has shown a correlation coefficient of 0.9.11

Figure 2 shows an actual tracing of flow wave forms and stroke volumes obtained along with other dynograph recorded parameters.

Four acid-base states were produced and studied; metabolic acidosis and alkalosis, respiratory acidosis and alkalosis. Metabolic acidosis data was obtained by two methods. A form of exogenous metabolic acidosis was produced by the intra- 


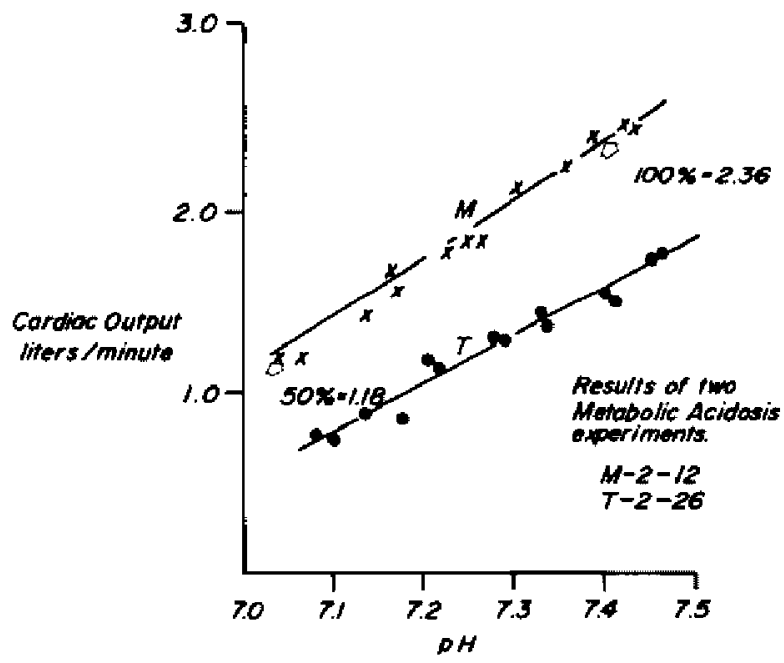

FIGURE 3

Data from two metabolic acidosis experiments illustrates the linear relationship of $\mathrm{pH}$ to cardiac output with $\mathrm{Paco}_{3}$ constant.

venous infusion of $20 \mathrm{mls}$ of $0.6 \mathrm{~m}$ hydrochloric acid. Metabolic acidosis data was also obtained by subjecting animals to deliberate hypoxia. Cardiac output measurements and arterial blood gas determinations were made approximately 25 and 40 minutes after acid infusion, or after 20 minutes recovery from hypoxia. Metabolic alkalosis was produced by the intravenous infusion of $30 \mathrm{mls}$ of 5 per cent sodium bicarbonate. Once again cardiac output measurement and blood gas determinations were made approximately 25 and 40 minutes after alkali infusion.

Respiratory acidosis was studied during alterations of respired concentrations of carbon dioxide at steps of $0,5,10,15,20,15,10,5$, and 0 per cent. Cardiac output measurements and blood gas determinations were obtained 20 minutes after each change in percent carbon dioxide. Respiratory alkalosis data were obtained using constant volume hyperventilation and incremental removal of mechanical dead space. Cardiac output determinations and blood gas determinations were obtained 20 minutes after each decrease in mechanical dead space.

A laboratory animal was subjected to one acid base state on one laboratory day. Occasionally, an animal was re-subjected to the same acid-base state to determine whether similar results would be obtained. Where possible, laboratory animals were subjected to other acid-base states after a suitable recovery period from earlier experiments. These animals were only used when baseline values for cardiac output and blood gas determination were shown to be similar to previous acid-base studies.

\section{Results}

Metabolic acidosis data showed a series of cardiac output values at varied $\mathrm{pH}$ levels consequent upon hydrochloric acid infusion. Figure 3 represents sample 


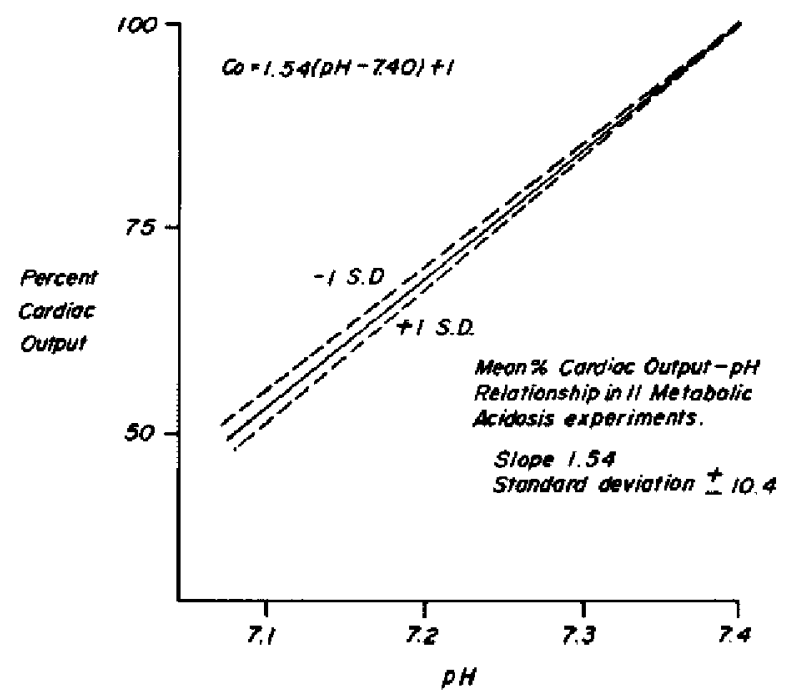

Froure 4

Data from all metabolic acidosis studies converted tora percentage to show the linear relationship of $\mathrm{pH}$ to percent cardiac output. A mathematical equation is shown for this linear relationship.

data from two animals which show that cardiac output declines in a linear fashion with decreasing pH, with $\mathrm{PCO}_{2}$ held constant at $40 \pm 3$ torr. Solid lines indicate the mean regression lines. In order to compare results from individual animals, cardiac outputs were converted to a percentage using the assumption that normal 100 per cent cardiac output occurred at a $\mathrm{pH}$ of 7.40. In example $\mathrm{M}, 100$ per cent cardiac output is 2.36 litres. The regression line shows 50 per cent cardiac output to be 1.18 litres at a $\mathrm{pH}$ of 7.02 .

When cardiac output data from eleven experimental animals are converted from litres/minute to a percentage of the normal cardiac output at $\mathrm{pH} 7.40$, it is possible to compare the change in percent cardiac output between all metabolic acidosis experiments. Figure 4 illustrates a comparison of 11 individual linear slopes for the percent cardiac output $-\mathrm{pH}$ relationship. The mean slope is 154 with a standard deviation of \pm 10.4 . This linear relationship between percent cardiac output and $\mathrm{pH}$ can be expressed mathematically as:

$$
\text { C.O. }=1.54(\mathrm{pH}-7.4)+1
$$

Metabolic acidosis studies require several points of clarification. Base-line values for cardiac output and blood gas measurements are obtained at the start of each procedure. After injection of hydrochloric acid or after a period of hypoxia, cardiac output was seen to increase above base-line values due to an increase in heart rate and a slight increase in stroke volume. In this study baseline values were taken, but not used to calculate cardiac output-pH relationships.

Normal blood gas values in the dog are not identical to humans. It is the experi- 
ence of this laboratory that both the anaesthetized and the conscious dog manifest a slight metabolic acidosis with normal $\mathrm{pH}$ of 7.35-7.38 and $\mathrm{PCO}_{2}$ of $34-38$. In this study six animals were shown to have a pH of approximately 7.30 after one infusion of hydrochloric acid. It was therefore necessary to take a further five animals, previously infused with sodium bicarbonate, to obtain actual recorded $\mathrm{pH}$ values above 7.40 after one acid infusion. Since the slopes of the five pre-treated animals were also linear and similar to the untreated animals, the relationship of percent cardiac output to $\mathrm{pH}$ was concluded to be constant from 7.40 down to 7.00 in eleven experimental animals.

Metabolic alkalosis studies were obtained from six dogs by intravenous infusion of sodium bicarbonate. Cardiac output rose linearly as $\mathrm{pH}$ increased consequent upon alkaline infusion; with the $\mathrm{PCO}_{2}$ stable at $40 \pm 3$ torr. Repetition of this procedure was continued to the point where cardiac output no longer increased or started to fall. The average $\mathrm{pH}$ for this point was 7.48. To compare individual experiments, cardiac output values were converted to a percentage and the individual slopes of percent cardiac output plotted against $\mathrm{pH}$ were compared. The mean slope was 146.7 with a standard deviation of \pm 36.4 . The relatively slight difference in slopes between metabolic acidosis and alkalosis may be due to the volumes of buffer infused, or to the addition of bicarbonate ions. Metabolic studies therefore reveal the linear relationship of cardiac output to $\mathrm{pH}$ through a $\mathrm{pH}$ range of approximately 7.00 to 7.50 .

It is interesting at this point to analyze cardiac output values above 7.48. Preliminary studies reveal that a parabolic relationship is suspected around this point. A rise in $\mathrm{pH}$ above 7.48 produces a fall in cardiac output; which becomes greater as the $\mathrm{pH}$ rises. It is also postulated that the optimum $\mathrm{pH}$ for cardiac output may be below 7.48 but that the addition of volumes of buffers may be the cause and effect of cardiac output increase.

Respiratory acidosis data were obtained from seven dogs subjected to incremental increases in carbon dioxide. Observed cardiac output was shown to increase with each increment in respired carbon dioxide and decreased as carbon dioxide was withdrawn. The results from one respiratory acidosis experiment are illustrated in Figure 5.

With acid and alkali infusions, the $\mathrm{PCO}_{2}$ was held constant at $40 \pm 3$ torr to evaluate the effect of the changing $\mathrm{pH}$. In order to evaluate the effect upon cardiac output of $\mathrm{PCO}_{2}$ changes per se, it would be desirable to maintain $\mathrm{pH}$ constant at 7.4. However, during hypercapnoea there is an inherent change in $\mathrm{pH}$ accompanying the $\mathrm{CO}_{2}$ accumulation. Therefore, changes in cardiac output from carbon dioxide are the result of the combined effects of $\mathrm{pH}$ and $\mathrm{PCO}_{2}$. To evaluate the stimulant effect of carbon dioxide elevation from the opposed depressant effect of $\mathrm{pH}$ requires a devious method.

A factor is applied from the percent cardiac output-pH relationship previously obtained in Figure 4 from metabolic acidosis studies. Each observed cardiac output was mathematically adjusted to the value which would have been obtained by that level of carbon dioxide had there been no depressant effect of $\mathrm{pH}$ changes coincident to hypercapnoea. The result is as though $\mathrm{pH}$ had been held constant at 


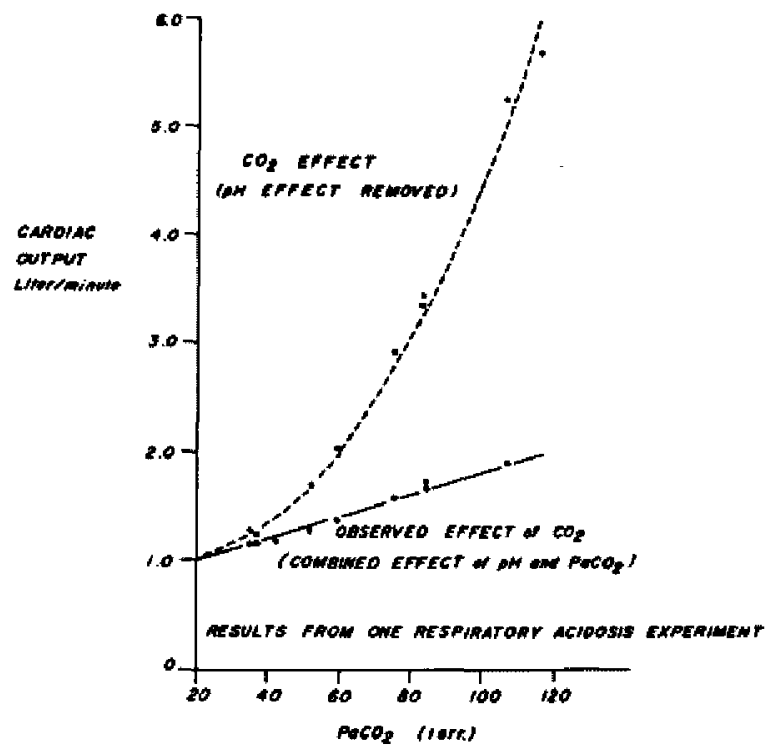

Figure 5

The solid line illustrates the results of one respiratory acidosis study with combined $\mathrm{pH}$ and $\mathrm{PaCO}_{2}$ effects on cardiac output. The dashed line illustrates the exponential relationship of $\mathbf{P a C O}$ to cardiac output when $\mathrm{pH}$ effect is mathematically eliminated ( $\mathrm{pH}$ adjusted).

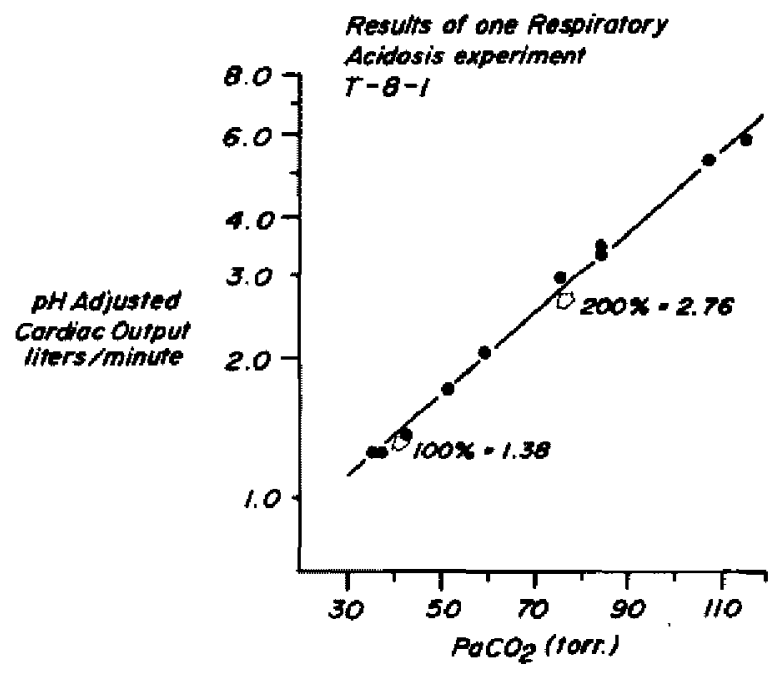

Figure 6

Data from Figure 5 is converted to a straight line by plotting on semi-logarithmie paper to show the linear relationship of $\mathrm{PaCO}_{2}$ to $\mathrm{pH}$ adjusted cardiac output. 


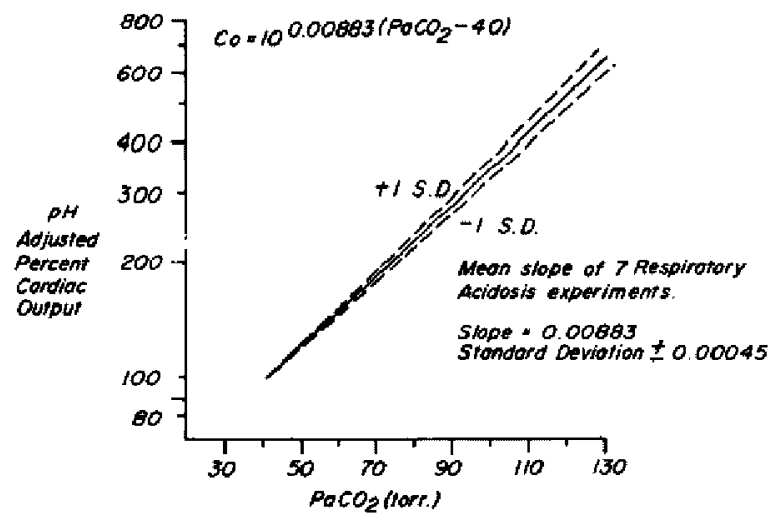

Figure 7

Data from all respiratory acidosis studies converted to a percentage to show the linear relationship of $\mathrm{PaCO}_{2}$ to $\mathrm{pH}$ adjusted percent cardiac output. A mathematical equation is shown for this linear relationship.

7.4. The exponential relationship of $\mathrm{pH}$ adjusted cardiac output to $\mathrm{PCO}_{2}$ per se is evident in Figure 5.

This exponential relationship can be converted to a straight line when $\mathrm{pH}$ adjusted cardiac output is plotted on a logarithmic scale against $\mathrm{PCO}_{2}$ on an arithmetic scale as shown in Figure 6. Data and the regression line from one hypercapnoea experiment are illustrated. Normal or 100 per cent $\mathrm{pH}$ adjusted cardiac output is assumed to occur at a $\mathrm{PCO}_{2}$ of 40 torr, which is 1.38 litres. A pH adjusted cardiac output of 200 per cent is 2.76 litres at a $\mathrm{PCO}_{2}$ of 76 torr on the mean regression line.

Conversion of $\mathrm{pH}$ adjusted cardiac output in litres/minute to a percentage change allows comparison between hypercapnoea experiments. A comparison of individual slopes for seven hypercapnoea experiments is illustrated in Figure 7. The mean slope is 0.00883 with a standard deviation of \pm 0.00045 . The relationship between percent $\mathrm{pH}$ adjusted cardiac output and $\mathrm{PCO}_{2}$ can be expressed mathematically as:

$$
\text { C. } O .=10^{0.00883\left(\mathrm{PeO}_{2}-40\right)}
$$

Respiratory alkalosis data were obtained in 5 dogs using constant volume hyperventilation and incremental removal of mechanical dead space. Cardiac output was observed to decrease with hypocapnoea. When observed cardiac output was $\mathrm{pH}$ adjusted and converted to a percentage, the mean slope from hypocapnoea studies was 0.01823 with a standard deviation of \pm 0.0022 . These findings are similar to our own observations with fluroxene ${ }^{6}$ and to the observation of Morgan et al. ${ }^{12}$ with nitrous oxide and oxygen, that cardiac output decreased during respiratory alkalosis. Other factors may account for the hypocapnoea slope. They include possible changes of mean intrathoracic pressure with time, subsequent decrease in venous returm, and reduced sympathetic nervous system activity during respiratory alkalosis observed by Moster et al. ${ }^{15}$

The separate and opposed effects upon cardiac output of $\mathrm{pH}$ and $\mathrm{PCO}_{2}$ can be 


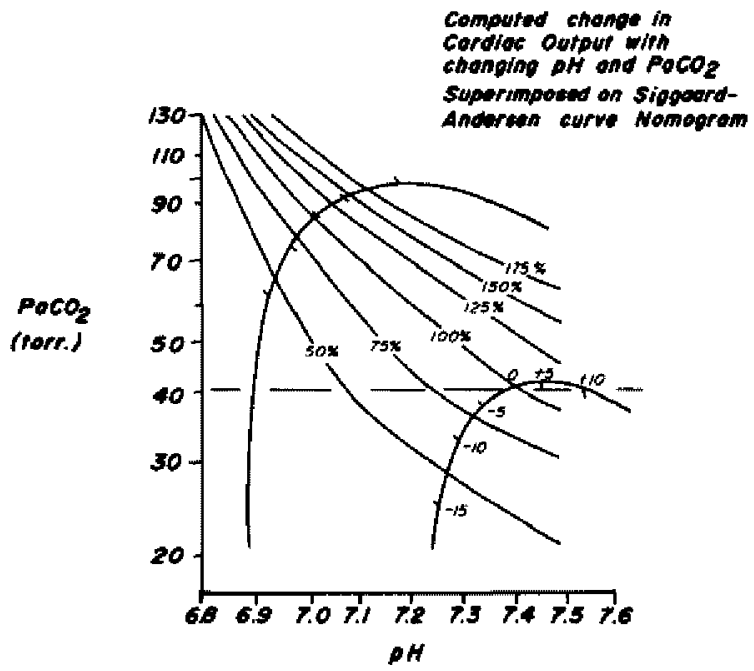

Figure 8

A nomogram is illustrated to predict percent cardiac output for any $\mathrm{pH}$ and $\mathrm{PaCO}_{2}$ values. This is based on observed cardiac outputs with varied acid-base states measured in this study.

combined mathematically. The computed cardiac output is a product of the $\mathrm{pH}$ effect upon cardiac output, the $\mathrm{PCO}_{2}$ effect upon cardiac output, and the normalized or 100 per cent cardiac output at $\mathrm{pH} 7.4$ and $\mathrm{PCO}_{2} 40$.

$$
\mathrm{C}^{1} \mathrm{c}^{\mathrm{l}}=[1.54 .(\mathrm{pH}-7.40)+1]\left[10^{0.00883}\left(\mathrm{PaCO}_{3}-{ }^{40)}\right] \mathrm{C \dot {N }}\right.
$$

When cardiac output observed in hypercapnoea studies is compared with computed cardiac output, the correlation co-efficient is 0.91 . The co-efficient of variance is 3.6 per cent. Hypocapnoea studies revealed a similar correlation co-efficient of 0.93 . The co-efficient of variance is 4.1 per cent.

The excellent correlation shown between observed and computed cardiac output enables the derivation of a computed nomogram to predict the effect of any paired values of $\mathrm{pH}$ and $\mathrm{PCO}_{2}$ upon cardiac output. The derived nomogram illustrated in Figure 8 is superimposed on the Siggaard-Andersen nomogram to show percentage cardiac output values of $50,75,100,125,150$ and 175 per cent at various $\mathrm{pH}$ and $\mathrm{PCO}_{2}$ values. The nomogram reflects computed change within the range of measurements in this study. It may be useful to give two examples from the nomogram. Metabolic acidosis with a $\mathrm{pH}$ of 7.15 and $\mathrm{PCO}_{2}$ of 35 would be expected to produce a cardiac output of 50 per cent of normal. Respiratory acidosis with a $\mathrm{pH}$ of 7.12 and $\mathrm{PCO}_{2}$ of 70 would be expected to produce a cardiac output of 100 per cent due to $\mathrm{PCO}_{2}$ stimulation balancing $\mathrm{Co}$-incident opposed $\mathrm{pH}$ depression.

\section{Conclusions}

The effects upon cardiac output of induced metabolic and respiratory changes were studied in dogs during methoxyflurane anaesthesia. Cardiac output declined 
in a linear fashion when $\mathrm{pH}$ was altered from 7.48 to 7.04 by acid and alkali infusion, while $\mathrm{Pco}_{2}$ was held constant at $40 \pm 3$ torr. Cardiac output increased moderately with a rising $\mathrm{PCO}_{2}$ from 16.5 to 132 torr, despite concomitant changes in $\mathrm{pH}$. When observed cardiac output was mathematically adjusted to maintain $\mathrm{pH}$ at 7.4, the $\mathrm{pH}$ adjusted cardiac output was shown to increase in an exponential fashion with $\mathrm{PCO}_{2}$ elevation.

The response of cardiac output to changes in $\mathrm{pH}$ and $\mathrm{PcO}_{2}$ occurred in predictable fashion. Equations were utilized to express the separate relationships of $\mathrm{pH}$ and $\mathrm{PCO}_{2}$ to cardiac output. The combined effect of $\mathrm{pH}$ and $\mathrm{Pco}_{2}$ upon cardiac output was expressed mathematically to obtain computed cardiac output. A nomogram was presented to show expected percentage change in cardiac output at any combination of $\mathrm{pH}$ and $\mathrm{PCO}_{2}$ values.

This study warrants several statements to be made for clinical anaesthesia. Alterations in acid-base states in patients undergoing anaesthesia should affect cardiac output. The degree and extent of cardiac output changes may vary widely from this study done in dogs, but it should be considered when severe derangements in acid-base status occur. This animal model has now been used to study halothane, ${ }^{,}$fluroxene, ${ }^{6}$ and methoxyflurane. It is obvious that similar models utilized to study other agents, will permit scientific comparison to be made of the effects of all inhalation anaesthetic agents on cardiac output. The results of such studies may eventually dictate which specific agent will have the soundest physiological basis for use in a particular acid-base disturbance.

\section{ACKNOWLEDGEMENTS}

The author wishes to acknowledge the assistance of Dr Lucien E. Morris and Dr D.C. Lee and appreciation for their knowledge and direction in this project. Further appreciation must be given to the staff technicians of our Anaesthesia Research Laboratory, the Medical Art Department at St Michael's Hospital, and secretarial staff of the Department of Anaesthesia, St Michael's Hospital, University of Toronto.

This project was supported by a medical research Council grant MA 3376 . Methoxyflurane was graciously supplied by Abbott Laboratories Ltd.

\section{RÉSUMÉ}

Au cours de lanesthésie au méthoxyllurane sur des chiens, nous avons étudié les effets sur le débit cardiaque de changements respiratoires et métaboliques provoqués. Le débit cardiaque a diminué de façon linéaire lorsque le $\mathrm{pH}$ a été modifié de 7.48 à 7.04 par l'infusion d'acide ou d'alcalin alors que la $\mathrm{PCO}_{2}$ était maintenue constante à $40 \pm 3$ torr. Le débit cardiaque a augmenté légèrement avec l'augmentation de la $\mathrm{Pco}_{2}$ de 16.5 à 132 torr, malgré les changements conconittants du $\mathrm{pH}$. Lorsque le débit cardiaque observé était mathématiquement ajusté pour maintenir le $\mathrm{pH}$ à 7.4, le débit cardiaque ajusté au $\mathrm{pH}$ augmentait de façon exponentielle lorsqu'on élevait la $\mathrm{PCO}_{2}$.

La réponse du débit cardiaque aux changements de $\mathrm{pH}$ et de $\mathrm{PCO}_{2}$ survient de façon prévisible. Nous avons utilisé des équations pour exprimer les rapports séparés du $\mathrm{pH}$ et de la $\mathrm{PCO}_{2}$ avec le débit cardiaque. L'effet associé du $\mathrm{pH}$ et de la 
$\mathrm{PCO}_{2}$ sur le débit cardiaque a été exprimé de façon mathématique pour obtenir le débit cardiaque en ces circonstances. Nous avons présenté un nomogramme pour indiquer le pourcentage de changement prévu du débit cardiaque à n'importe quelle variation des valeurs du $\mathrm{pH}$ et de la $\mathrm{PCO}_{2}$.

Cette étude permet de faire plusieurs affirmations sur l'anesthésie clinique. Des modifications de l'équilibre acide-base chez des malades soumis à l'anesthésie devraient modifier le débit cardiaque. Le degré et les limites des changements du débit cardiaque peuvent varier beaucoup selon cette étude faite sur des chiens, mais il faut en tenir compte s'il survient de forts dérangements de léquilibre acide-base. Actuellement, nous avons utilisé cet animal type pour étudier l'halothane, ${ }^{5}$ le fluroxène $e^{\theta}$ et le méthoxyflurane. Il est évident que de semblables modèles utilisés pour étudier d'autres agents vont permettre de faire une comparaison scientifique des effets de tous les agents anesthésiques par inhalation sur le débit cardiaque.

Les résultats de telles études pourront éventuellement indiquer quel agent spécifique sera le choix le plus physiologique à employer dans un cas particulier de déséquilibre acide-base.

\section{REFERENCES}

1. Nc, M.L. ;Evy, M.N.; \& Zneske, H.A. The Effects of Changes of pH and of Carbon Dioxide Tension on Left Ventricular Performance. Am. J. Physiol., 213: 115-120 (1967).

2. CAREss, D.L.; KISSACK, A.S.; Stovin, A.J.; \& StuCkEY, J.H. The Effect of Respiratory and Metabolic Acidosis on Myocardial Contractility. J. Thorac: \& Cardiovasc. Surg, 56: 571-577 (1968).

3. ANDERSEN, M.N., \& Mountrzen, C, Effect of Acute Respiratory and Metabolic Acidosis on Cardfac Output and Peripheral Resistance. Ann. Surg., 163; 161-168 (1966).

4. Carson, S.A.; Chorley, G.E.; Hamit.TON, F.N.; LEE, D.C.; \& MonRis, L.E. Variation in Cardiac Output with Acid-Base Changes in the Anaesthetized Dog. J. Suppl. Physiol., 20: 948-953 (1965).

5. Tomlin, P.J.; Schlobohm, H.M.; Cafson, S.A.; \& Mohnis, L.E. Variations in Cardiac Output with Acid-Base Changes in the Halothane Anaesthetized Dog. Brit. J. Anaesth., 38: 660 (1966).

6. Storks, W.W.; Murfhy, P.V.; \& Morris, L.E. Cardiac Output Variations with Acid-Base Change During Fluoromar Anaesthesia. Fed. Am. Soc. Exper, Biol., April, 1970. (ahstr.)

7. Ecer, E.I.; Bandstater, B.; Samman, L.J;; Regan, M.J;; Severinghaus, J.W.; \& Munson, E.S. Equipotent Alveolar Concentrations of Methoxyflurane, Halothane, Diethylether, Fluroxene, Cyclopropane, Xenon, and Nitrous Oxide in the Dog. Anesthesiology, 26: $771-777$ (1965)

8. Rosenthal, T.B. The Effect of Temperature on the $\mathrm{pH}$ of Blopd and Flasma in Vitro. J. Biol. Chem, 173: 25-30 (1948).

9. Bradlex, A.F.; Stupfed, M.; \& Sevringahaus, J.W. Effect of Temperature on $\mathrm{PCO}_{2}$ and $\mathrm{Po}_{2}$ of Blood in Vitro. J. Appl. Physiol., 9: 201-204 (1956)

10. SCrEr, A.M.: ZepepA, I.; \& Brown, O.F. Square-wave Electromagnetic Flowmeter Em. ploying Commercially Available Recorder. J. Appl. Physiol., 18: 1265-1267 (1963).

11. Hamlion, F. Norman; Minzel, J.C.; \& Schlobohm, Richard M. Measurement of Cardiac Output by Two Methods in Dogs. J. Appl, Physiol., 22; 362-364 (1967).

12. Morgan, B.C.; Ghawford, E.W.; Horneein, T.F.; Martin, W.E.; G Guntheroth, W.G. Hemodynamic Effects of Changes in Arterial Carbon Dioxide Tension During Intermittent Positive Pressure Ventilation. Anesthesiology, 28: 866 (1967).

13. Theye, R.A.; Mride, J.H.; \& Mickenfetomer, J.D. Effect of Hypocapnea on Cardiac Output During Anesthesia. Anesthesiology, 27; 778 (1966).

14. Mongan, B.C.; Martin, W.E.; Honnbein, T.F.; Crawfond, E.W.; \& Gunthenoth, W.G. Hemodynamic Effects of Intermittent Positive Pressure Respiration. Anesthesiology, 27: 584-590 (1966).

15. Moster, W.G.; Reier, C.E.; Candier, R.W.; \& Hamelaera, W. Cardiac Output and Postganglionic Sympathetic Activity During Acute Respiratory Alkalosis. Anesthesiology, 31; 28-34 (1969). 